SHORT REPORT

\title{
Hazardous drinkers in the accident and emergency department-Who accepts advice?
}

\author{
R Patton, M Crawford, R Touquet
}

Emerg Med J 2004;21:491-492. doi: 10.1136/emj.2003.011403

Aims: To identify factors that predict acceptance of brief advice among people consuming excessive alcohol in an accident and emergency (A\&E) department.

Methods: Patients presenting to an A\&E department were screened using the Paddington Alcohol Test. All patients identified as hazardous drinkers were offered advice about their drinking. Data were collected on patients' age, sex, presenting condition, and alcohol consumption. Binary logistic regression was used to identify variables that predicted acceptance of the offer of advice.

Results: The presenting condition, together with the total number of units consumed on a single occasion, predict the uptake of an offer of help.

Conclusions: Patients identified as hazardous drinkers who present after a fall, head injury, or other accident are less likely to accept help. Clinicians should emphasise the potential relation between alcohol consumption and health related consequences to encourage the uptake of advice for these patients.

$\mathrm{S}$ udies carried out specifically in the general hospital setting suggest that brief interventions can lead to significant reductions in alcohol use or related problems, or both. ${ }^{1}$ Reported barriers to the implementation of brief intervention centre upon a failure to identify hazardous drinkers. $^{2}$

The work of Huntley et $a^{3}$ showed that selective screening of just 10 presenting conditions could account for up to $77 \%$ of hazardous drinkers, who could then be offered access to interventions designed to reduce their consumption. No matter how effective an intervention may be, it is reliant upon the willingness of a patient to accept it. The identification of underlying characteristics associated with the rejection of brief interventions could help clinicians to shape the way in which screening results are presented to patients, and thus increase the proportion of hazardous drinkers willing to accept help. We have found that by emphasising the potential connection between the hazardous pattern of alcohol consumption and the possible future consequences to health, patients are more likely to accept the offer of an intervention. ${ }^{4}$

\section{PARTICIPANTS/METHODS/RESULTS}

As part of a wider randomised controlled trial investigating screening and brief intervention in the A\&E department of a large inner London teaching hospital, 1120 non-treatment seeking hazardous drinkers (aged 18+) were identified using the Paddington Alcohol Test ${ }^{5}$ over a one year period $(21.4 \%$ of all patients screened). Of these 717 accepted an intervention $(64.0 \%)$. Screening occurred as per routine practice, ${ }^{34}$ with senior house officers first dealing with the patients' primary presenting condition, and then asking questions about their drinking. Male patients consuming eight or more units of alcohol on any single occasion at least once per week, or female patients consuming six or more units, or any patient who declared that their visit to the A\&E department was alcohol related were recognised as hazardous drinkers, were told that their level of alcohol consumption may be harmful, and offered help. Patients who did not accept the offer of help were provided with contact details of local alcohol agencies, should they reconsider.

Tables $\mathrm{IA}$ and $\mathrm{IB}$ shows differences in proportions among the demographics and presenting circumstances of patients who did or did not accept our offer of help. Binary logistic regression showed that a patient's presenting condition, together with the total number of units consumed on a single occasion, predicts uptake of the intervention. There was a significant positive association between presentation to the A\&E department complaining of abdominal pain/discomfort and accepting advice (77.7\%). A significant negative association was detected for head injury $(52.9 \%)$, accident $(55.4 \%)$, or after a fall $(59.8 \%)$.

\begin{tabular}{|c|c|c|c|}
\hline \multirow[b]{2}{*}{ Number (\%) } & \multirow{2}{*}{$\frac{\text { Accepted advice }}{n=717(64.0)}$} & \multirow{2}{*}{$\begin{array}{l}\text { Did not accept advice } \\
\mathrm{n}=403(36.0)\end{array}$} & \multirow{2}{*}{$\frac{\text { Difference in proportion }}{(95 \% \mathrm{Cl})}$} \\
\hline & & & \\
\hline Age in years (mean) & 44.2 & 42.8 & $1.4(-0.5$ to 3.3$)$ \\
\hline Sex: male & 560 (78.2) & $263(76.5)$ & $1.8(-7.2$ to 3.6$)$ \\
\hline $\begin{array}{l}\text { Average units consumed during } \\
\text { drinking session }\end{array}$ & 21.44 & 18.61 & $2.82(0.98 \text { to } 4.67)^{* *}$ \\
\hline $\begin{array}{l}\text { Believed initial A\&E attendance } \\
\text { related to drinking }\end{array}$ & $358(70.1)$ & $185(69.8)$ & $0.3(-7.0$ to 6.6$)$ \\
\hline $\begin{array}{l}\text { Attended A\&E up to six months } \\
\text { before randomisation }\end{array}$ & $219(30.8)$ & $98(28.8)$ & $2.0(-6.2$ to 5.4$)$ \\
\hline
\end{tabular}


Table 1 (B) Proportion of patients who accepted advice

\begin{tabular}{llll}
\hline \multicolumn{2}{l}{ Specific presenting condition } & All other conditions & Difference in proportion $(95 \% \mathrm{Cl})$ \\
\hline Fall & $107(59.8)$ & $609(69.1)$ & $-9.3(-17.2 \text { to }-1.6)^{*}$ \\
Collapse & $111(68.1)$ & $605(67.4)$ & $0.7(-7.1$ to 8.4$)$ \\
Head injury & $37(52.9)$ & $679(68.6)$ & $-15.7(-27.8 \text { to }-3.7)^{* *}$ \\
Assault & $78(71.6)$ & $638(67.1)$ & $4.5(-4.5$ to 13.5$)$ \\
$\mathrm{NSGl}$ & $87(77.7)$ & $629(66.4)$ & $11.3(3.1 \text { to } 19.6)^{*}$ \\
Unwell & $101(66.9)$ & $615(67.7)$ & $-0.8(-8.9$ to 7.3$)$ \\
Psychiatric & $62(72.9)$ & $654(67.1)$ & $5.8(-4.0$ to 15.8$)$ \\
Cardiac & $49(74.2)$ & $667(67.1)$ & $-1(-3.8$ to 18.1$)$ \\
Accident & $31(55.4)$ & $685(68.2)$ & $11.1(-0.1$ to 21.4$)$ \\
Other & $53(77.9)$ & $663(66.8)$ & \\
\hline \multirow{2}{*}{$\mathrm{p}<0.05 ;{ }^{* *} \mathrm{p}<0.01}$. & &
\end{tabular}

\section{COMMENT}

A patient's age or sex alone does not predict the uptake of an offer of brief intervention. However, presenting condition and current level of alcohol consumption are associated with the acceptance of an offer of help.

Underlying reasons for the negative association between falls, head injuries, accidents, and the acceptance of alcohol related advice are unclear. These patients display insight as to the relation between their injuries and alcohol, yet they remain resistant to advice. One possible explanation might be that such events such as falls and accidents are believed to be attributable in part to misfortune or other factors over which the patient has no control.

Most patients identified as hazardous drinkers (64\%) accepted the offer of advice, however all hazardous drinkers may benefit from an intervention that aims to reduce their alcohol consumption. It may be possible to increase the proportion of patients who present after a fall, head injury, or accident that accept advice by further emphasising the relation between their drinking and possible health consequences, as well as the potential link between alcohol and their presentation to the A\&E department.

\section{Authors' affiliations}

R Patton, M Crawford, Imperial College, London, UK

R Touquet, Accident and Emergency Department, St Mary's Hospital, London, UK

Funding: none.

Conflicts of interest: none declared.

Correspondence to: Dr R Patton, SLaM/Institute of Psychiatry, National Addiction Centre, 4 Windsor Walk, Denmark Hill, London SE5 8AF, UK; r.patton@iop.kcl.ac.uk

Accepted for publication 28 February 2004

\section{REFERENCES}

1 Royal College of Physicians. Alcohol-can the NHS afford it? London: Royal College of Physicians, 2001.

2 D'Onofrio G, Bernstein E, Bernstein J, et al. Patients with alcohol problems in the emergency department. Part 2: Intervention and referral. Acad Emerg Med 1998:5:1210-17.

3 Huntley JS, Blain C, Hood S, et al. Improving detection of alcohol misuse in patients presenting to an accident and emergency department. Emerg Med J 2001;18:99-104.

4 Patton R, Crawford MJ, Touquet R. Impact of health consequences feedback on patients' acceptance of advice about alcohol consumption. Emerg Med J 2003;20:451-2.

5 Patton R, Touquet R. The Paddington Alcohol Test. Br J Gen Pract 2002;52:59. 


\section{PostScript}

\section{CORRECTIONS}

doi: 10.1136/emj.2004.015586corr l

In the short report titled, Not all cases of neck pain with/without torticollis are benign: unusual presentations in a paediatric accident and emergency department (Emerg Med J 2005: 22:645-8) two errors have occurred. The corresponding address for A Natarajan is incorrect and should be Consultant Paediatrician, anatarajan@hotmail.com. The second error is in the legend for figure 1. It should read ' $\mathrm{Tl}$-weighted MRI scan of the cervical spine showing a large intramedullary tumour in the cervical and upper thoracic region C1-T2.' The journal apologises for these errors.
An author's error occurred in the paper titled Hazardous drinkers in the accident and emergency department-Who accepts advice? (Emerg Med J 2004;21:491-2). Incorrect proportions for 'Believed initial AED attendance related to drinking' appear in table $\mathrm{l}$ (A). The figures were calculated using a denominator based on the number of responses to that item, rather than the number of patients who were offered advice. The correct proportions are 49.9 for 'Accepted advice' and 45.9 for 'Did not accept advice' (not 70.1 and 69.8 as stated in the text). The difference in proportion $(95 \% \mathrm{CI})$ should read $4.0(-2.1$ to $10.1)$.
In the paper titled, Comparison of the effectiveness of intravenous diltiazem and metoprolol in the management of rapid ventricular rate in atrial fibrillation (Emerg Med J 2005;22:41 1-4) an error has occurred in table 4 . At 20 minutes, places of systolic and diastolic pressures were exchanged. The author apologises for this error.

doi: 10.1136/emj.2005.002005

In part 15 of the $\mathrm{ABC}$ of community emergency care (Emerg Med J 2005;22 564-71) the legend for figure 2 is incorrect. It should read 'Sixth nerve palsy right eye: failure of abduction. Courtesy of Dr P Marazzi/SPL model released'.

\section{Clinical Evidence-Call for contributors}

Clinical Evidence is a regularly updated evidence-based journal available worldwide both as a paper version and on the internet. Clinical Evidence needs to recruit a number of new contributors. Contributors are healthcare professionals or epidemiologists with experience in evidence-based medicine and the ability to write in a concise and structured way.

Areas for which we are currently seeking authors:

- Child health: nocturnal enuresis

- Eye disorders: bacterial conjunctivitis

- Male health: prostate cancer (metastatic)

- Women's health: pre-menstrual syndrome; pyelonephritis in non-pregnant women However, we are always looking for others, so do not let this list discourage you.

Being a contributor involves:

- Selecting from a validated, screened search (performed by in-house Information Specialists) epidemiologically sound studies for inclusion.

- Documenting your decisions about which studies to include on an inclusion and exclusion form, which we keep on file.

- Writing the text to a highly structured template (about 1500-3000 words), using evidence from the final studies chosen, within 8-10 weeks of receiving the literature search.

- Working with Clinical Evidence editors to ensure that the final text meets epidemiological and style standards.

- Updating the text every six months using any new, sound evidence that becomes available. The Clinical Evidence in-house team will conduct the searches for contributors; your task is simply to filter out high quality studies and incorporate them in the existing text.

- To expand the topic to include a new question about once every 12-18 months.

If you would like to become a contributor for Clinical Evidence or require more information about what this involves please send your contact details and a copy of your CV, clearly stating the clinical area you are interested in, to Klara Brunnhuber (kbrunnhuber@ bmigroup.com).

\section{Call for peer reviewers}

Clinical Evidence also needs to recruit a number of new peer reviewers specifically with an interest in the clinical areas stated above, and also others related to general practice. Peer reviewers are healthcare professionals or epidemiologists with experience in evidence-based medicine. As a peer reviewer you would be asked for your views on the clinical relevance, validity, and accessibility of specific topics within the journal, and their usefulness to the intended audience (international generalists and healthcare professionals, possibly with limited statistical knowledge). Topics are usually 1500-3000 words in length and we would ask you to review between 2-5 topics per year. The peer review process takes place throughout the year, and our turnaround time for each review is ideally 10-14 days.

If you are interested in becoming a peer reviewer for Clinical Evidence, please complete the peer review questionnaire at www.clinicalevidence.com or contact Klara Brunnhuber (kbrunnhuber@bmigroup.com). 